\section{SIR RODERICK MURCHISON}

THE life of a scientific man is for the most part uneventful, and perhaps to the world at large uninteresting. That he was born, lived a certain number of years, and died, are often the chief facts chronicled of the man himself. Of his work and of the influence of his work men are willing to read, but for the story of his life, with its quiet everyday monotony, they care little. Yet it is true, at least of the higher type of mind, that the story of the man's life and the history of the work he accomplished are inseparably connected, and are each necessary for the un lerstanding of the other. Ther: arise, too, ever and anon instances when the man was not merely a man of science, but one whose scientific career formed as it were a nucleus round which many other and often divergent interests gathered. Such a man's life is sometimes linked in so many ways with that of the society in which he lived, that its chronicle becomes in some degree the history of his time. And such a man was Roderick Impey Murchison. By no means standing on the highest platform of scientific intellect, a patient gatherer of facts rather than a brilliant generaliser from them, he yet gained by common consent in the commonwealth of science the position of a king, under whom men of all ranks, and even men of far higher ability and attainment than his own, were not only willing but delighted to serve. He held a place which no other man of science left among us now fils. It was not merely his achievements in geology, memorable as these were, which gave him that proud pre-eminence, nor did he owe anything to success in other branches of science, for he seldom travelled beyond what he knew to be his proper domain, nor to graces of literary style, on which men of slender acquirements often float

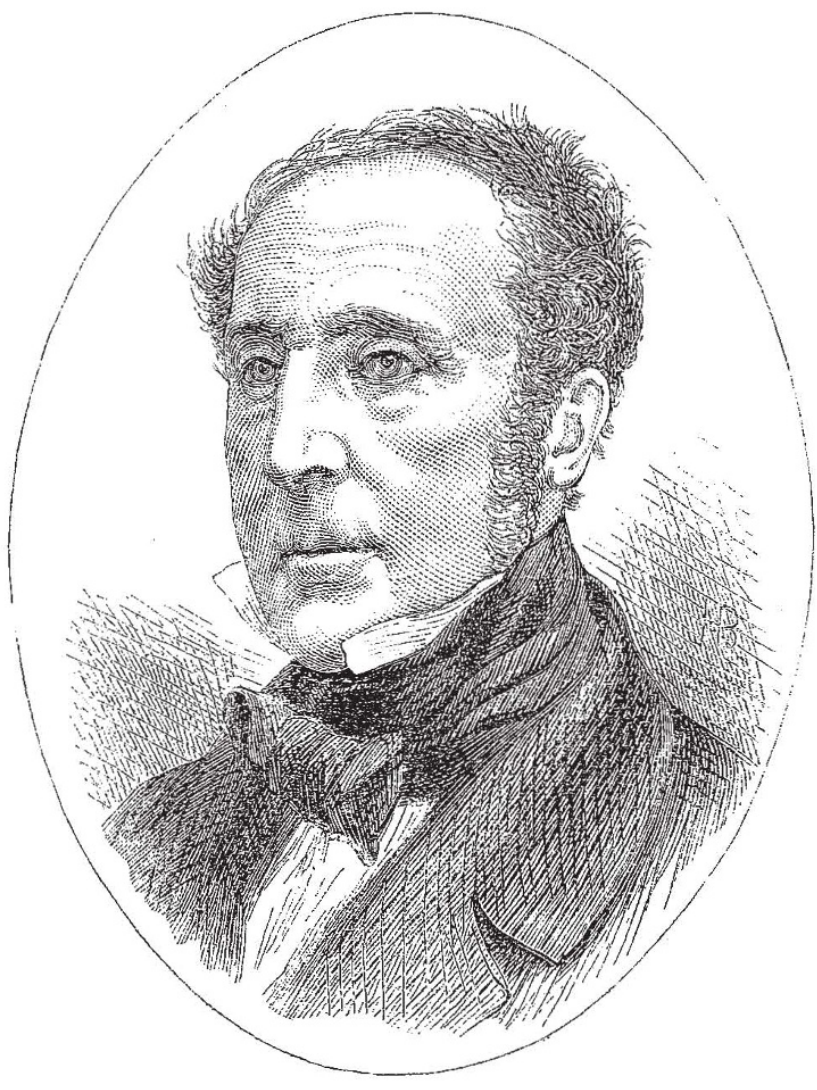

THE LATE SIR RODERICK I. MURCHISON

into popularity. He wrote only on geological and geographical subjects, and in a solid matter-of-fact way not likely to attract readers who did not previously care for his subjects. It was his personal character, his noblehearteaness, his indomitable energy, his tact and courtesy, the dignity and grace which he never failed to show even to opponents, and the social position which his family and fortune gave him, and which enabled him greatly to extend the respect shown in society to science and scientific men, -it was these causes which largely went to make Sir Roderick's influence what it was. A narrative, to do him justice, should tell how these causes came into play, and how, combined with the regard which he could always claim for his solid contributions to science, they placed him so high in the scientific circle in which he moved.

Murchison was born on February 19, 1792, at his father's little estate of Tarradale, in E... - Ro.s.shire. He used to speak with fondness of the fact that he first saw the light amid those old palæozoic sandstones, con. glomerates, and schists, on which he was afterwards to rest part of his title to fame. Yet it was not among the wilds of Ross that he acquired a love for rocks. He was removed from his birthplace at an early age, and taken into Dorsetshire, and though when still a child he was brought back into Scotland, and remained with his mother at Edinburgh for a short while, it was in England that he spent most of his boyhood, and where he was educated. At the age of fifteen he obtained a commission in the 36th Regiment of Foot, and served in the Peninsula under Sir Arthur Wellesley. He carried the colours at the Battle of Vimiera, and went through much hardship in the retreat of Corunna. At the end of the war, 
after having become a captain of dragoons, he quitted the army, and marrying the daughter of General Hugonin, settled in England. So ended what he used to call the military episode of his life. Next came the foxhunting period, when his activity of disposition found vent in the excitement of the chase, into which he threw himself heart and soul. He might have continued a merry, hearty, sporting, country gentleman, but for the influence of his wife, who was fond of natural history pursuits, and the advice of Sir Humphrey Davy, who, meeting him at the house of Mr. Morritt, of Rokeby, and seeing in him promise of something better than foxhunting, advised him to attend the Lectures of the Royal Institution. Sir Roderick used to tell an interesting anecdote of that early beginning of his scientific career. $\mathrm{He}$ was attending the lectures of (if we remember) Dr. Brande, when one day the lecturer's place was taken in his absence by a pale thin lad, his assistant, who gave the lecture and experiments in so admirable a manner as to be received at the end with a hearty round of applause. It was Michael Faraday, and this was his first public appearance.

After gaining considerable knowledge from public lectures and private instruction, Sir Roderick's active mind sought as early as possible to study Nature in the field. Geology was the branch of science which suited best a nature so fond of out-of-door life as his. He had made the acquaintance of William Smith, the father of English Geology, from whose own lips he had learned the order of succession which the marvellous patience and ingenuity of that pioneer of the science had made out for the rocks of England and Wales, and indeed, as was afterwards found, for the rocks of all the world. In the year 1825 , when he was thirty-three years of age, he wrote his firstpublished paper, "A Geological Sketch of the Northwestern Extremity of Sussex and the adjoining parts of Hants and Surrey." From that time on wards for nearly half a century he continued to furnish accounts of his observations in the field. Beginning, as was natural, with the district in which he lived, he soon extended his researches even as far as his own native Highlands, then step by step over the Continent of Europe, even as far as the confines of Asia. He has published more than Ioo memoirs on British and Continental Geology, besides numerous addresses to scientific societies, and in addition to upwards of twenty memoirs in conjunction with other authors. To all this mass of work must be added what he published in separate volumes-his great "Silurian System," his splendid volumes on "Russia," and the successive editions of his "Si'uria."

of the incidents of his life during its scientific period it is not necessary here to say much, nor to try to count up the honours showered on him from all parts of the world. There was hardly a scientific Academy anywhere which had not enrolled him among its associates, and to the dignities conferred on him by his own Sovereign, were added others conferred by Emperors and Kings abroad. His time was largely passed in London, where he took an active share in scientific work. But every year he made a tour either in this country or on the Continent, and added to our knowledge of the geological structure of the districts which he visited. Sometimes these tours were prolonged, and in the case of his Russian campaign he was absent for two or three years from England.

At the time when Murchison broke ground as a geologist, the science of geology had entered a new phase of its history. The absurd system of Werner, though still upheld by high authority in this country, was daily losing ground, and the simple and obvious classification of William Smith on the one hand, and the doctrines of Hutton on the other, were guiding all the younger intellects of the day. Murchison's tact is nowhere more conspicuous than in his choice of a field for the exercise of his patient energy of research. He saw that the old Wernerian notion of "transition" rocks was doomed, and that it would be a task well worthy of his time and toil to unravel the succession of these rocks, and try to introduce into them the same order and consistency which Smith had shown to mark the Secondary series of England. He chose for the scene of his researches the border country of England and Wales, where these old rocks are well displayed, and after five years of unremitting labour he produced his "Silurian System"-a work, which, though dealing only with the rocks of a limited tract of Britain, yet first unfolded the earlier chapters of the history of life upon our globe. The classification he adopted, though of course necessarily subject to local variation and change, has been found to hold true on the great scale over the whole world.

This work laid the foundation of Sir Roderick's fame. In his subsequently published "Siluria," which bas gone through several editions, he recast the original work, introducing much detail regarding the extension of Silurian and older palæozoic rocks into other countries ; but while in the later publication, the results given were necessarily often the work of other observers-the "Silurian System" remains a monument of the unaided labour of a mind quick in observation, sagacious in inference, patient in the accumulation of data, and full of that instructive appreciation of the value of facts not yet understood, which is near of kin to genius.

It would be beyond the limits of this journal to offer an adequate outline of Sir Roderick's scientific work. He was distinctly and specially a geologist. His early attachment to palæozoic rocks never waned, and though now and then he was led to make and record observations on later formations, he always returned to the older deposits as his natural inheritance and domain. $\mathrm{He}$ was not a palæontologist, but no geologist could use more skilfully than he the data furnished by palæontology. This faculty he acquired at the beginning of his career, and it marked all his work in the field both at home and abroad. It enabled him to apply to distant countries the principles which he had so successfully used in his own. Perhaps the leading idea of his scientific life should be regarded as the establishment of the order of succession among rocks. This was what he did in the Silurian region originally, and what he always endeavoured to ascertain in every district to which choice or accident might lead him. He had a singularly quick eye for the geological structure of a country. No one who travelled with him through a hilly tract, and, after listening to his rapid inferences, has gone actually over the ground to see, could fail to be struck with the accuracy with which he seized on some of the leading features, and from these deduced the general arrangement of the rocks. It was in this way, and by the use of palæontological evidence, that he was enabled to arrive at one of the most brilliant generalisations he ever achieved, when he brought order and intelligibility into the chaos of the so-called primary rocks of his own Scottish Highlands-a deduction which is, perhaps, destined to bear fruit of which he never dreamed, in the still obscure subject of metamorphism.

Sir Roderick Murchison's early training in geology was acquired at a time when men believed in periodic cataclysms, by which the surface of the globe was destroyed and renewed. He never could, and he never seemed seriously to try, to shake himself free from the influence of that training. Though he modified bis views as years went on, he remained a member, and indeed in this country the leader, of the Cataclysmic School. The upholders of a long line of successive creations and of the former greater intensity of all geological causes have lost in him one of their ablest, staunchest, and most influential associates.

To the world at large, however, it was not from his genlogical work chiefly that Murchison was known. His 
generalisation as to the probable gold-bearing nature of the Australian quartz-country, and as to the probable aspect of the interior of Africa, are probably familiar to most people. But in later years what has especially brought his name into prominence is the chivalrous devotion with which he has maintained one might almost say the national belief in the welfare of Dr. Livingstone. Yet this is only a sample, though one which has come more publicly before us, of the tenacious friendship and active penevolence which have always marked him. As President of the Geographical Society-a society which is in a sense his own creation-he had frequent opportunities of befriending not only-the cause of geography but the personal well-being of travellers, and he never failed to use them. The geographers have good cause to lament the death of their chief.

Of the man himself, what he was as he lived and moved among us, his loss is too recent to permit us justly to speak. We can only think of him as the stately courteous old gentleman, carrying even to the last that military bearing which dated from the days of Wellesley and Moore, kindly and thoughtful in his kindliness--a man whose friendship, once given, even ingratitude and injustice could not wholly alienate. He was not without some of the littlenesses of humanity, but they were so transparent, and often even so child-like, that we forget them in the recollection of all the goodness of heart and strength of head and nobility of nature which have gladdened us for so long, but which are now only subjects of tender remembrance.

\section{ARCH, GEIKLE}

\section{HOMOPLASY AND MIMICRY}

A LL students of the remarkable phenomenon of superficial resemblances in the animal and vegetable kingdom will be glad that Prof. Dyer has published an extension of the paper which he read on this subject at the Edinburgh meeting of the British Association. It is especially satisfactory that he has abandoned the very objectionable term "pseudomorphic," and substituted that of " homoplastic," a very much better term, because it simply expresses a fact without committing one to any theory. There are, however, one or two points in his paper of last week, on which I should wish to be allowed to comment.

Prof. Dyer holds that the distinction between "mimicry" in animals and "homoplasy" in plants, is "sufficiently obvious," the difference assigned being, apparently, that in the one case it takes place between species found in the same locality, in the other between species unconnected geographically. I doubt, however, whether facts will warrant this distinction. The most remarkable instances of "mimicry" among animals hitherto published are, undoubtedly, in the case of species inhabiting the same area; but I am inclined to think that, when attention is called to the subject, others will be found between animals not so associated, though these instances would naturally not attract so much observation. And secondly, homoplasy in plants does frequently occur in species occupying the same area. The statement reported to have been made by Prof. Dyer at Edinburgh that "the resembling plants are hardly ever found with those they resemble," would scarcely be borne out by a careful investigation. The real objection to the terms "mimicry" and "imitation" is that they seem to imply a conscious effort at convergence, which will hardly be conceded in the case of Lepidoptera any more than of Ferns. The substantial difference betweeen the two is that, in the case of animals, the resemblance appears to be protective, while in the case of plants, there is seemingly no such benefit arising from it ; but this is a difference in result and not in the nature of the phenomenon itself. I fail to see that the objections to the use of these terms in the case of plants do not equally apply to animals; we have no reason to suppose that the two sets of phenomena are not produced by similar causes.

Prof. Dyer states, and no doubt truly, that the external resemblances of plants may frequently be traced to the effect of similar external conditions, and quotes in support Mr. E. R. Lankester's view with regard to animals. But in assuming that this explanation will account for all such phenomena if fully investigated, I think too much is assumed. Cases of homoplasy are referable to two distinct classes-resemblances in general habit, and resemblances of particular organs. The former, as in the case of the homoplasy between a Cactus and a Euphorbia or a Stapelia, or between a Kleinia and a Cotyledon, are no doubt due to the operation of similar external conditions of climate and soil. But in the second class this explanation wholly fails.

As illustrations of the kind of resemblance I mean, I may refer to the two collections of "mimetic plants" exhibited by Mr. W. W. Saunders at the two last soirées of the Linnean Society, a list of which will be found in NATURE for May 26, 1870, and May 4, 1871. The extraordinary resemblance in the markings of the leaves in plants thus grouped together, might well deceive the most experienced botanist. To account for this homoplasy on the ground of similar external conditions, is to start a mere hypothesis, without any facts to warrant it. A still more curious series of resemblances occurs in the case of fruits than of leaves, so close that it has deceived botanists of the experience of the elder Hooker, Bentham, and Kunth into placing species in a genus with which they have no structural affinity whatever. I have in my mind in particular two samaroid fruits, both from the forests of Brazil, so absolutely identical in external facies, that dis. tinction is quite impossible without dissection, and yet belonging to exceedingly remote orders. I will not, however, say more on this point, as it would be impossible to appreciate the closeness of the homoplasy without drawings, which I hope shortly to be able to publish. The singular part of this resemblance is, that, as far as we know, it is never protective. In our Bee-orchis we have what might well have been assumed prima facie to be a case of protective resemblance, the flower being so fashioned in order to attract bees to assist in its fertilisation. It is remarkable, however, that the Bee-orchis is one of the few plants that appear to be perpetually selffertilised, never being visited by insects. It is just possible that we have an instance of protective or rather beneficial resemblance of scent in the case of the carrionlike odour of the flowers of Stapelia, which attracts bluebottle and other flies.

In a paper read at the recent meeting of the American Association for the Advancement of Science, by Prof, E. D. Cope, I find the following thoughtful remarks:- "Intelligence is a conservative principle, and will always direct effort and use into lines which will be beneficial to its possessor. Thus, we have the source of the fittest, i.e., addition of parts by increase, and location of growthforce directed by the will, the will being under the influence of various kinds of compulsory choice in the lower, and intelligent option among higher animals. Thus intelligent choice may be regarded as the originator of the fittest, while natural selection is the tribunal to which all the results of accelerated growth are submitted. This preserves or destroys them, and determines the new points of departure on which accelerated growth shall build."

Biologists generally are, probably, hardly prepared to apply the terms "intelligence" and "will" to the vegetable kingdom ; but the use of the term "vegetable life" seems to me to imply of necessity that there are powers at work in the econony of the plant, as of the animal, which it is vain to attempt to reduce to manifestations of the forces which govern the inorganic world.

Alfred W. BenNetT 